NBER WORKING PAPER SERIES

\title{
THE ROLE OF FOREIGN DIRECT INVESTMENT IN INTERNATIONAL CAPITAL FLOWS
}

Robert E. Lipsey

Working Paper 7094

http://www.nber.org/papers/w7094

\author{
NATIONAL BUREAU OF ECONOMIC RESEARCH \\ 1050 Massachusetts Avenue \\ Cambridge, MA 02138 \\ April 1999
}

The views expressed herein are those of the authors and do not necessarily reflect the views of the National Bureau of Economic Research.

(0) 1999 by Robert E. Lipsey. All rights reserved. Short sections of text, not to exceed two paragraphs, may be quoted without explicit permission provided that full credit, including ${ }^{\circledR}$ notice, is given to the source. 
The Role of Foreign Direct Investment

in International Capital Flows

Robert E. Lipsey

NBER Working Paper No. 7094

April 1999

JEL Nò. F21, F23

\section{ABSTRACT}

Direct investment has accounted for about a quarter of total international capital outflows in the 1990s and appears to have grown, relative to other forms of international investment, since the 1970s. The United States was by far the major source of direct investment outflows in the early 1970s, but Europe caught up to the United States in the 1980s and Japan almost did, before fading in the 1990s. The United States shifted from being the largest net supplier of direct investment to absorbing much of the world's supply, especially in the late 1980s, and then reverted to its earlier net supplier role.

Direct Investment flows have been the least volatile source of international investment for most countries, the chief exception being the United States, which has flipped back and forth from dominant net supplier to dominant net recipient, and back to dominant net supplier. Particularly for developing countries, direct investment has been the most dependable source of foreign investment.

Robert E. Lipsey

National Bureau of Economic Research

50 East 42nd Street, 17 th Floor

New York, NY 10017-5405

rlipsey@email.gc.cuny.edu 


\section{The Role of Foreign Direct Investment in International Capital Flows}

\section{Robert E. Lipsey}

\section{Introduction}

The purpose of this essay is to provide some quantitative historical background to the question of what role direct investment plays in the broader story of international capital flows. The essay examines whether that role has changed over time, or changed for some groups of investing or receiving countries, and how that role differs among countries and types of countries.

International flows of capital perform a variety of functions in the world economy. For example, they permit levels of domestic investment in a country to exceed the country's level of saving. That has been the case for the United States for the last 15 years and for most of the last 25 years. For rapidly growing economies, such as the United States and Argentina in the $19^{\text {th }}$ century, inflows of foreign investment permit faster growth, and/or growth with less sacrifice of current consumption, than could otherwise take place. For countries generating large amounts of saving, international capital flows provide a means to invest where returns are higher than at home, as was the case for Great Britain in the $19^{\text {th }}$ century and for Japan more recently.

These are long-term uses of what are, in some cases, prolonged periods of capital flows into or out of particular countries. Shorter periods of capital flows may serve some different functions, such as smoothing various types of cyclical or other economic fluctuations. For

\footnotetext{
* I am indebted to Shachi Chopra-Nangia and Ewa Wojas for able research and statistical assistance. An earlier version of this paper was presented at the NBER Conference on International Financial Flows in Woodstock, Vermont, October 16-18, 1997.
} 
example, Edelstein (1982) has suggested that while inward capital flows to the United States during the $19^{\text {th }}$ century were not large relative to domestic capital formation over long periods, they were much more important in shorter periods when capital formation spurted far ahead of more slowly growing saving levels, financing booms in capital formation that might otherwise have been strangled by rising interest rates. Countries heavily dependent on particular crops need capital flows to finance periods when crops fail or when crop prices fall drastically, permitting consumption, and perhaps capital formation, to be at least partially sheltered. International capital flows can also help to finance periods of war or of reparations, sometimes resulting from defeats in wars.

When these uses of international capital movements are studied, the flows of capital are usually measured net, as the difference between outflows and inflows, rather than by examining outflows and inflows separately. That is partly out of necessity, for lack of gross flow data. Most international capital flows during the $19^{\text {th }}$ century are approximated by estimates of the net balance on current transactions, where it can be estimated, or even by the merchandise trade balance, where it cannot. One exception to this rule is that there have been many studies of flotations of foreign securities during the $19^{\text {th }}$ century, particularly in the British capital market. Some of the components of the balance on capital account are, even now, usually observed in the form of net outflows or inflows; the simultaneous, or almost simultaneous, purchases and sales of different types of equity, of government securities, of private bonds, and of short term debt is not observable for many countries.

Flows of direct investment capital are an exception to this netting out of outward and inward flows; for many countries, data are available separately for outward and inward flows. The outward flows are measured as the flows involving firms based in the reporting country, 
although these firms can, at times, repatriate their foreign investment, producing negative outward flows. The inward flows represent the activity in the country of firms based in other countries. The division reported now by the IMF, following this practice, is between "investment abroad" and "investment in" a country.

A possible way to explain the different treatment of direct investment, aside from the problems of collecting data, is that direct and portfolio investment are related differently to the financial markets in home and host countries. In the markets for bank loans, government securities, and private company bonds and equity, many buyers and sellers are competing with each other to supply and acquire fairly standardized types of assets with fairly well defined prices in identifiable markets. Changes in flows can presumably be associated with changes in various interest rates in markets for these types of securities. It may matter little in the French and UK corporate bond markets whether, for example, the UK demand for French corporate bonds and the French demand for UK corporate bonds both increase equally at the expense of demands for each country's own bonds, or both decrease equally in favor of their own countries' securities, or whether there is no change in any of these demands.

Direct investment flows, on the other hand, do not enter any general financial market. They are internal to each firm, and an inflow is not simply offset by an outflow. Each flow brings something different to a country because it is attached to a specific firm. Equal direct investments from France to Germany and Germany to France do not simply cancel each other out; there has been an addition to the stock of French skills producing in Germany and an addition to German skills producing in France. Thus, a comparison of net direct investment flows with aggregate net international investment misses much of the significance of direct investment. 
This contrast should not be drawn too sharply. Portfolio investment may also flow in two directions at any given time. Investors in country 1 make portfolio investments in country 2 while investors in country 2 are making such investments in country 1 . They may be seeking country or industry diversification in their portfolios even if their preferences and attitudes toward risk are the same. If they are not the same, investors in one country may be indulging a greater appetite for political risk or industry instability combined with higher returns.

The flow of direct investment is very much a two-way street among the top investing countries, even though direct investment is more concentrated among source countries than among recipient countries. The top ten exporters of direct investment capital accounted for over 90 per cent of the world total in 1989-1993 while the top ten recipients accounted for less than three quarters of reported inflows. Nevertheless, six of the top ten exporters were also among the top ten recipients, and two of the other top recipients ranked just below the top ten as exporters (World Bank, 1997). Another distinction between the exporter and importer groups was that the exporter group was a little more stable: eight out of the ten largest exporters of direct investment capital in 1969-73 were also in the group in 1989-93, while only six of the ten largest importers were still among the ten largest importers in 1989-93.

The data for the stock of outward and inward investment, which presumably reflect the cumulation of flows over many years, show similar concentrations. The top ten holders of direct investments abroad in 1995 owned 87 per cent of the world total, while the top ten host countries were the location of about two thirds of the stock. Six of the top host countries were also among the top ten holders (United Nations, 1996). 
2. The Definition and Measurement of Direct Investment: Control vs. "Lasting interest"

Direct investment is often discussed as if it consisted entirely of the investment associated with multinational corporations. Such a concept would match the theoretical literature on direct investment, but the data available do not follow it. There are many aspects of multinational corporation activity not included in measures of direct investment and all past and present definitions of direct investment include transactions that do not involve multinationals.

The definition of direct investment, and therefore its measurement, have changed considerably over time. Definitions and measurements even now differ among countries despite the efforts of international agencies to push for uniformity.

The United States was a pioneer in surveying both outward and inward direct investment. The object of the surveys, as described in the 1937 inward investment survey, was to measure “...all foreign equity interests in those American corporations or enterprises which are controlled by a person or group of persons.... domiciled in a foreign country" (U.S. Department of Commerce, 1937, p. 10). The term "equity interest" encompasses all holdings of common and preferred stock, advances, and intercompany accounts. No definition of "control" is provided, but control is the criterion for inclusion.

The outward survey for 1950 (U.S. Department of Commerce, 1953) does provide a definition of direct investments, “...the United States equity in controlled foreign business enterprises....as statistically defined for the purposes of this survey" ( p. 4). Four categories were covered:

1. "Foreign corporations, the voting securities of which were owned to the extent of 25 percent or more by persons or groups of affiliated persons, ordinarily resident in the United States..." 
2. "Foreign corporations, the voting stock of which was publicly held within the United States to an aggregate extent of 50 percent or more, but distributed among stockholders, so that no one investor, or group of affiliated investors, owned as much as 25 percent."

3. "Sole proprietorships, partnerships or real property (other than property held for the personal use of the owner) held abroad by residents of the United States."

4. "Foreign branches of United States corporations..."

Three of these categories are part of current measures of direct investment, but the second one is not. An earlier definition had been even broader, including publicly owned companies with as little as 25 per cent of stock in scattered U.S. holdings. The definition of control has been narrowed to mean ownership by a company, a person, or a small affiliated group. The change eliminated from the total of U.S. outward direct investment mainly Canadian companies, probably including such companies as Canadian Bell and Alcan Aluminium, that for historical reasons had large numbers of non-corporate U.S. holders.

The current definition of direct investment, endorsed by the OECD (1996) and the International Monetary Fund (1993) avoids the idea of control in favor of a much vaguer concept. "Foreign direct investment reflects the objective of obtaining a lasting interest by a resident entity in one country ("direct investor") in an entity resident in an economy other than that of the investor ("direct investment enterprise"). The lasting interest implies the existence of a long-term relationship between the direct investor and the enterprise and a significant degree of influence on the management of the enterprise" (OECD, 1996, pp. 7-8).

While this concept is a vague one, the recommended implementation is specific. "OECD recommends that a direct investment enterprise be defined as an incorporated or unincorporated enterprise in which a foreign investor owns 10 per cent or more of the ordinary shares or voting 
power of an incorporated enterprise or the equivalent of an unincorporated enterprise....An effective voice in the management, as evidenced by an ownership of at least 10 per cent, implies that the direct investor is able to influence, or participate in the management of an enterprise; it does not require absolute control by the foreign investor" (OECD, 1996, p. 8).

The idea of control, which is behind much of the literature on multinationals, has been specifically abandoned. The Fifth edition of the IMF Balance of Payments Manual points out (p. 86) that the concept of direct investment now used "....is broader than the SNA concept of foreign-controlled, as distinguished from domestically controlled resident enterprises." A single "direct investment enterprise" could be part of several different multinational firms, possibly from several countries. Duplication is avoided in investment flow and stock data, the main areas of concern to the OECD and the IMF, by allocating the financial aggregates to the various owners according to the extent of their ownership. However, data on the activities of multinationals, particularly those collected by home countries on, for example, the sales, employment, or output of their multinational firms or their overseas operations, could easily contain duplication if this 10 per cent criterion is used.

\section{Historical Background}

\section{a. Direct Investment Before World War I}

The history of multinational firms, and of the cross-border capital flows associated with them, foreign direct investment, goes back a long time. Mira Wilkins reminds us that “...the origins of American multinational enterprises go back to the colonial period..." and that "Multinational enterprise headquartered in Europe has a longer history than American business abroad, going back to the middle ages (1977, p. 577). She describes "modern" American 
multinational corporations as dating from the 1850 s and “...investments over borders of modern European-headquartered manufacturing companies...to have accelerated in the late nineteenth and early twentieth centuries." She suggested that historical studies of international capital flows “...often short-changed foreign direct investment."

It is striking, in view of the current interest in multinationals and foreign direct investment, that many descriptions of pre-World War I capital flows, perhaps the largest in history relative to total income or fixed investment, either did not discuss direct investment at all (Iverson, 1936),or combined it with portfolio investment, as in the compilation in Palgrave (1910, Vol. II), without considering whether the determinants or effects were similar. However, Hobson (1914) did describe a half-century or more that “...has witnessed an enormous rise in the importance of the international company, in railways, mining, tramways, water, gas, electricity, banking, insurance, finance, land plantations, and other enterprises" (p.125). "The international company has even extended to manufacturing, but there it is still somewhat rare..." In one of his early books, John Dunning (1970) described the pre-World War I situation by the statement that "In 1914, 90 per cent of all international capital movements took the form of portfolio investment- i.e., the acquisition of securities ...issued by foreign institutions, without any associated control over, or participation in their management....several American and European companies ...already owned sizeable foreign manufacturing ventures, but these were the exceptions rather than the rule, and they rarely accounted for a major part of the enterprises' total activities." (p. 2).

The consensus was probably well summarized by Arthur Bloomfield's appraisal that "Portfolio investment was a far more important component of long-term capital movements before 1914 than direct investment..." (p. 3), although Bloomfield noted one exception, China, 
among host countries, and one, the United States, among investing countries. Another apparent exception among investing countries, heavily weighted by investment in China, was Japan, with almost 90 per cent of its foreign investment in the form of direct investment, as indicated in a number of sources cited by Mira Wilkins (1986). Bloomfield also noted that "Before $1914 \ldots$ the concept of direct investment (in its present-day sense) was not clearly distinguished from other (noncontrolling) equity investments in private foreign enterprises (Bloomfield, 1968, pp. 3-4).

The idea that direct investment flows were negligible before 1914 was challenged, at least as it applied to investment in developing countries, by Peter Svedberg (1978) who claimed that it was an illusion stemming from the typical methods of estimating flows and stocks. These relied heavily on compilations of government bond purchases and holdings and on London stock exchange and other similar flotations. They therefore missed many direct investments that did not pass through the exchanges. Also, by assuming that none of those that were publicly floated were bought by controlling interests, the estimates classified some direct investment as portfolio investment. After reviewing the data, Svedberg estimated that some $44-60$ per cent of the $\$ 19$ billion of accumulated investment in developing (or "underdeveloped") countries in 1913-14 was in the form of direct investment. Furthermore, similar ratios could be found for investment in many different areas and by many different home countries, and was not peculiar to investment by the United States.

Whatever the correct picture for the world before 1914, the history of U.S. inward international capital flows in that period conforms to the traditional picture. Foreign investment in the United States was overwhelmingly portfolio investment, to the extent that just before World War I about 80 per cent of the stock of long-term investment in the United States was 
portfolio investment (Lewis, 1938, p.546). Federal, state, and local governments and railways were the chief borrowers, and most of the borrowing was in the form of bonds rather than equity.

On the other side of the balance sheet, three quarters of the U.S. outward investment stock in 1914 was in the form of direct investment ( Ibid, p. 605). Thus, even if it is true that the worldwide role of direct investment before 1914 has been understated in the historical literature, its large role in U.S. outward investment was outside the range of other capital exporting countries' experience and far greater than in other countries' capital exports to the United States.

The divisions between domestic and foreign financing and between direct and portfolio investment can be thought of as ways of dividing up risks among different types of investors and borrowers. One could imagine that in the early history of the United States, foreign capital might have financed risky types of capital formation that domestic investors would avoid. However, the nature of the projects financed by foreign capital does not support this idea. Early foreign investment went mainly into government securities, probably thought of as relatively safe, although some of them proved riskier than was expected. Later investment went heavily into railroads. A common feature, aside from lending to the Federal government during the Civil War, was that foreign portfolio investment went to large, lumpy, social overhead capital projects, railroads, canals, and later, public utilities, relatively safer investments and less dependent on local knowledge than the typically much smaller, and on that account, riskier enterprises in agriculture or manufacturing, which were left mainly to local financing (Edelstein, 1982, pp. 3941, 237-238).

There were many manufacturing enterprises set up by foreign craftsmen or entrepreneurs with special skills. Since transportation and communication were so slow that it was impossible to manage these enterprises from abroad, the investment was therefore often accompanied by the 
migration of children or other relatives of the foreign investors to manage the enterprise.

Although these enterprises were a form of direct investment, they were different from most direct investment now in that they were not controlled by parent firms as an outgrowth of their businesses, but by individual investors. Mira Wilkins (1989) refers to these as "free standing enterprises." Over time they tended to become increasingly independent and often eventually lost the status of direct investments when their owners migrated to the United States.

b. The Dominance of Direct Investment in U.S. Investment Abroad and of the United States in World Outward Direct Investment

The United States has been, since its earliest days as a foreign investor, exceptionally focussed on direct investment. An estimate for 1897, when the United States was still predominantly a recipient of capital from abroad rather than a supplier, showed more than 90 per cent of U.S. outward investment to be direct investment. By 1914, the share had declined to three quarters, still far above the proportion in foreign investment in the United States or in world investment as a whole (Lewis, 1938, p. 605).

The period of World War I saw the first major U.S. portfolio investment abroad, including large loans to foreign governments that outweighed total private financing. By the end of 1919, direct investment had been reduced to a little over half of U.S. private investment abroad but to less than a quarter of total foreign investment including intergovernment loans (Lewis, 1938, p.447). The 1920s were characterized by rapid growth in both direct and portfolio private investment abroad, but were unlike the earlier periods in that portfolio investment became the predominant avenue for U.S. investment, tripling in value while direct investment only doubled, and accounting for over 60 per cent of the growth in private U.S. investment 
abroad. By 1929, the value of U.S. private portfolio investment exceeded that of direct investment for the first time (Lewis, 1938, pp. 450 and 605).

The Great Depression reversed the change in the composition of the U.S. private foreign investment portfolio that had taken place in the 1920s. Half of the foreign loans extended in the late 1920s went into default (Mintz, 1951, p. 6). U.S. holdings of securities, even valued at par, were reduced by almost 30 per cent (almost 50 per cent with defaulted bonds at market value), and short-term credits were cut almost in half (Lewis, 1938, p.454). By 1940, direct investment was back to 60 per cent of U.S. private outward investment. It was a little more than that in 1950 and remained between 60 per cent and two thirds through 1970 (U.S. Bureau of the Census,1975, Series U 26 - U 39).

U.S. government loans to foreign countries had expanded further during World War II and by 1950 were almost twice the total of all private investment stocks. Thus the restored dominance of direct investment in 1950 applied only to private investment. After 1950, U.S. government loans did not increase greatly and by 1970, more than 70 per cent of U.S. international assets were private and almost half were direct investment.

The United States not only had much or most of its international investment in the form of direct investment but also accounted for a large part of the world's stock of direct investment. In 1960, almost half of all the outward direct investment was owned by investors based in the United States. No other country came close; the next ranking holder of direct investment was the United Kingdom, at 18 per cent, followed by The Netherlands, at 10 per cent and France, at 6 per cent (United Nations, 1988, Table 1.2). The large role of direct investment in U.S. foreign investment was associated with a large role for the United States in the world's direct investment universe. 


\section{The Importance of FDI in Total International Investment Flows}

The first question we attempt to answer here is about the size of direct investment flows relative to other forms of international investment. For almost all countries, a three-way division is published by the IMF, separating international investment flows into Direct investment, Portfolio investment, and Other investment.

The definition of direct investment has been discussed above. Portfolio investment includes equity securities, debt securities in the form of bonds, money market instruments, and financial derivatives, such as options, all excluding any of these included in direct investment or reserve assets. The distinction between long- and short-term formerly made has been abandoned on the ground that original maturity is now of relatively little importance. The final category of “Other investment" includes trade credit, loans, financial leases, currency, and deposits, mostly short term assets.

The categories do not match those of the pre-1980 data we use, and some of the following tables therefore show an overlap for 1980-1984. The data for years before 1980 are on a similar basis to later ones for direct investment, reported as "investment by," mainly outflows from the reporting country, and "investment in," mainly inflows into the reporting country. That is the case for most flows, but there can be reverse flows on both sides. A country's firms can repatriate accumulated earnings from their foreign affiliates, or sell foreign operations to foreign buyers, resulting in a negative outflow (a positive entry in the balance of payments), and foreign firms in a host country can repatriate earnings or sell operations, producing a negative inflow of capital (a negative entry in the balance of payments). 
For categories other than direct investment, the flows before 1980 are reported on a net basis, not distinguishing between changes in assets and changes in liabilities. There is thus no natural world total for those categories because every transaction should enter as both an asset change and a liability change, and the total should therefore be zero. For these categories we approximate gross flows very roughly by aggregating the net flows of those countries that report net outflows in that category in each year. That is, we aggregate all the negative balance of payments entries in each year under the headings of "Portfolio investment, net," and "Other investment, net." The alternative of aggregating positive entries should give the same result if the data were complete, but of course they are not. Judging by the 1980-84 overlap, the 1969-79 estimates for portfolio investment outflow are understated by almost 30 per cent and those for "Other investment" by almost half.

The amounts of the three major types of investment flows, by these imperfect measures, are shown in Appendix Table 1. All types of international capital flows increased enormously. Since these are nominal values, they reflect the rise in world nominal income, which was, in 1990-94, about 5\&1/2 times as high as in 1970-74. All the forms of international capital flow grew faster than world nominal income. If we take the overlap in 1980-84 as an indicator of the underestimate of gross flows during 1970-1979, we would conclude that the flow of direct investment grew the most and that "Other Investment" hardly grew faster than income (Table 1). Since 1980, where we do have estimates of gross flows, portfolio investment has grown somewhat faster than direct investment, and "Other Investment" hardly grew until 1995, when it jumped ahead of the other two.

The long-term trend, if there is one, seems to have been an increase in the share of direct investment in total investment flows from 1980 through 1994, and possibly since 1970 (Table 2). 
After 1994, the trend was apparently reversed, with a burst of portfolio and "Other" investment, but the direct investment share remained well above that of the early 1970s.

All these statements have an important cloud over them. That is the persistent world current account deficit that has remained stubbornly close to $\$ 100$ billion a year, instead of zero, as it should be. That deficit, which is really a discrepancy item, is so large that it implies that the correct figures for some of these entries could be very far different from those we are relying on to study and to follow investment flows. The latest indicator of how far some of these numbers are from the facts they are supposed to represent is the results of the recently completed survey of U.S. portfolio investment abroad, which found that the market value of U.S.-owned foreign securities at the end of 1994 was $\$ 910$ billion instead of the previously estimated $\$ 556$ billion, an addition of 64 per cent.

\section{The Geography of International Investment Flows}

a. Origins and Destinations of Direct Investment

Outward direct investment originates mainly in the highest income countries, as can be seen from Appendix Table 2. The United States was the chief source of direct investment in 1970-74, larger than all the other regions shown here put together. Europe caught up in the second period and then far surpassed the United States. Japan caught up in 1985-89, and even

exported more direct investment capital than the United States during those years, although it is a considerably smaller economy, with GDP less than three quarters of that of the United States in nominal terms and less than 40 per cent in real terms. After 1990, Japan faded as a direct investor and the United States resumed its position as the largest single supplier of direct investment. 
The most rapid growth in outward direct investment was in the two developing areas, Developing Asia and Latin America, especially the former. By 1990-1994, according to the IMF data, the outflow from the Developing Asian countries had reached over 85 per cent of the Japanese level. However, these data grossly understate the contribution of Developing Asian countries and its growth in recent years by omitting Hong Kong, even though they include Taiwan, decorously concealed under the title, "Asia not specified." The addition of Hong Kong doubles the figure for the outflow from Southeast Asia in 1990-94. Hong Kong was a larger supplier of direct investment funds than Japan in 1994, 1995, and 1996 (UN 1997, Annex Table 13.2) and its addition to the Developing Asia total brings that region to an important position as a direct investor. The timing of the growth in Hong Kong's outward investment is similar to that in China's inward investment, confirming the impression that much of the investment was going to China. Although there is no reported surge in Hong Kong inward investment it is hard not to suspect that some part of the outward investment originated outside Hong Kong.

The flows to the main regional destinations for foreign direct investment are described in Appendix Table 3. The two outstanding shifts in the destinations of FDI flows over the quarter century were toward Asian countries, both China and Southeast Asia, and toward the United States. The flow to the United States reached a peak in the 1980s, when it was larger than the combined flows to all European destinations combined. After that, the flow to the United States receded somewhat, and in the next period the major growth was in the flow to Europe. Direct investment into Developing Asia continued to grow rapidly and that to Latin America revived. In 1990-94, Europe resumed its earlier position as the main destination of direct investment. Most of the increase over the previous period was matched by similar growth in European outflows, an indication that a large part of the growth was in intra-European investment. 
There is more direct evidence on the nature of European FDI. If Europe were treated as a single unit, its importance as a source and destination for FDI would be greatly reduced. Among the European countries that publish inward FDI position data, all except the UK had received 60 per cent or more of their FDI stock from other European countries. And among those that published outward FDI positions, all except the UK had sent half or more of their FDI to other locations within Europe (OECD, 1998).

Inflows into the United States have been volatile in the 1990s, first dropping to low levels in 1991 and 1992 and then rebounding strongly. Inflows into Japan, always small, turned negative in 1989 and, after a brief flurry in the early 1990s, stayed below \$1 billion per year in 1993-96. Inflows into China, already far above earlier amounts, took off after 1991, reaching over \$42 billion, almost 10 times the 1991 level, in 1996 (United Nations, 1997). There has been some suspicion that part of direct investment in China originates from China itself, routed through Hong Kong for various reasons including favorable treatment accorded to foreignowned enterprises in China. If that is the case, such "round trip" investment does not appear to be substantially financed by reported Chinese direct investment in Hong Kong, which is quite small relative to inward direct investment in China.

The major elements of the net flows of international capital in these regions since 1969 are summarized in Appendix Tables 4 through 6. Negative numbers represent net outflows of capital and positive ones, net inflows.

Europe and Japan were consistent net suppliers of direct investment to the rest of the world and Latin America was a consistent absorber of such capital, as was Developing Asia, especially in the last period (Appendix Table 4). In 1993-95, China far surpassed Latin America as a net importer of direct investment (UN, 1997, Annex Tables B.1 and B.2). One odd case here 
is the United States, which shifted from being the world's major net supplier of direct investment during the 1970s to being a large net recipient throughout the 1980s before returning to its traditional role. The shift is sometimes attributed to the devaluation of the dollar that started in 1985, and it is true that the inflow was at its largest in 1987 to 1989, but the United States switched to being a net importer of direct investment capital much earlier, in 1981, and was a net importer through the period when the dollar was at its highest. Something more than exchange rates must have been at work. The other switch was in Southeast Asia which, after absorbing direct investment on balance from 1969 to 1992, became a net supplier, mainly on account of Hong Kong, after that.

The net flow of portfolio capital does not show the same consistency of direction as the direct investment flow and some of the fluctuations are very large (Appendix Table 5). Japan has been a pretty consistent capital exporter in this category since the 1970s, while the other regions have mostly been importers. For the United States, portfolio inflows were particularly large in 1985-89, just when direct investment inflows were also at a peak. In this period, the high inflow into the United States almost exactly matched the outflow from Japan. The fact that the peak period in the United States was the same as for direct investment suggests that whatever led to the large inflows was not peculiar to direct investment. In Latin America, also, the jump in direct investment inflows in the 1990s was accompanied by a large rise in portfolio capital inflows. For the whole period since 1980, the regions listed reported imports of portfolio capital reaching over $\$ 1 \frac{1 / 4}{4}$ trillion, while the only net exporter in the list, Japan, reported less than half that amount in exports (Table 3).

In the case of other capital flows, only one region, Europe, was consistent over time with respect to the direction of the flows, with inflows in every period (Appendix Table 6). Every 
other region had periods of both inflows and outflows, sometimes with abrupt shifts from one to the other. The United States was a net supplier of funds through 1979-83 and then turned to being a net recipient. Latin America was almost always a supplier of funds, and the other countries showed no consistent role.

\section{c. The Regional Distribution of Total Net International Investment Flows}

The combination of the various types of net capital flows is the total net international flow of capital. Japan has been a consistent supplier of capital on the international market throughout the whole period since 1980, while the United States has been a major net recipient of international capital flows, especially in the most recent years (Appendix Table 7). Southeast Asia and Latin America have been pretty continuous recipients and were relatively large ones except when the United States began to absorb foreign capital on a large scale in 1983. Europe has mostly absorbed capital on net balance except in the $1985-89$ period.

\section{Differences in Behavior among Types of International Financial Flows}

\section{a. Volatility}

As was mentioned in the discussion of historical aspects of international investment, above, different types of financial flows can perform quite different functions for both investing and receiving countries. One difference among the types of flows that affects their functions, especially for the recipients, is in their volatility, a subject that has received increased attention

since the Asian crisis began. We can compare flows of different types by asking how often net flows to or from a country change signs. That is, how often do inflows turn into outflows and outflows turn into inflows. 
For direct investment, among the 52 countries for which we have long runs of data, and data for each type of capital flow, the average number of reversals was 2.50 , indicating an average run in a single direction of almost eight years (Table 4). The next most stable type was portfolio investment, with 3.60 reversals, on average, an average run in one direction of four and a half years. Other capital flows reversed signs 4.2 times on average. Thus, the general impression of the relative stability of direct investment, relative to the other types, is confirmed.

These comparisons take account of the direction of flows but not the size, which can vary sharply without any change of direction. We compare the types of flow with respect to their standard deviations in Table 5.

In the case of the United States, both portfolio and short-term capital flows fluctuated less relative to the average flows than did net direct investment. The United States was unusual in this respect, however. For Japan and for the three regions, the averages for individual country volatility, as measured by the ratios of standard deviations to means, was lowest for net direct investment. The volatility of the aggregates in two of the three regions confirmed the relative stability of direct investment. There is a particularly wide gap in Latin America between the volatility of net portfolio investment and the relative stability of net direct investment.

\section{b. Relations Among Capital Flows}

If flows of direct investment respond to current economic conditions in each country, one might expect to find alternating periods of larger outflows than inflows and larger inflows than outflows and, therefore, a negative relationship between gross outflows and gross inflows. As Table 6 indicates, for a selection of major exporters and recipients of FDI flows, that is not the case. By and large, where there is a significant relationship, it is a positive one; direct investment inflows into a country tend to be large when outflows from the country are large. 
To some extent, this relationship may reflect trends, or simply the effects of growth, which we may partially remove by taking international flows relative to GDP. The trend influence is confirmed by the fact that fewer equations are significant, the correlations are lower, and one significant negative relationship appears, for Brazil, but the overall result is still that outflows and inflows are positively related, where there is any significant relationship at all.

We can also ask how gross or net FDI outflows are related to flows of capital in other forms. The results for the 13 countries used in the test are presented in Table 7.

The strongest relationship is that between outward direct investment and outward flows of short-term capital. Large outflows of direct investment are accompanied by outflows of shortterm capital as well. There is also a much weaker positive association with net flows of portfolio capital. Net outflows of direct investment are negatively correlated with net flows of all other long-term capital and also with that part of it that is portfolio capital. Little of the variability in one flow is explained by the other but there is at least some suggestion here of substitution among types of long-term capital flows, especially between direct and portfolio capital flows.

\section{c. The Importance of Retained Earnings in Direct Investment}

One feature of flows of direct investment that distinguishes it from other forms of investment is that it can be, and often is, financed from the retained earnings of affiliates. The IMF and the OECD recommend that direct investment flows include "...the direct investor's share of the company's reinvested earnings" (OECD,1996, p. 16). Unfortunately for our ability to make comparisons across countries, many important capital exporters do not include reinvested earnings in their capital flow data. Among the OECD countries, Belgium, Canada, France, Italy, Japan, and Norway are in this group. 
The United States is one country that has kept records of retained earnings of its firms' foreign affiliates over many years, although there have been some changes in their treatment in the Balance of Payments. The distribution, by type, of U.S. direct investment outflows in recent years is described in Table 8.

Although there are large fluctuations in the proportions, reinvested earnings are clearly the predominant form of financing of U.S. outward direct investment. They account for more than half of investment over the whole period, in each sub-period, and in ten out of the fourteen individual years. The only year in which they were not larger than each of the other forms of investment was the severe recession year, 1982.

One reason for the importance of reinvested earnings in U.S. outward direct investment is that U.S. firms' foreign operations are relatively mature, having started earlier than most of those from other countries. However, the large role of reinvested earnings is an old one for the United States. During the late 1930s and through World War II they were virtually the only source of additions to direct investment, and even when the pace of investment picked up after the war, retained earnings still provided over 40 per cent of the growth.

In the 25 years from 1950 through 1975, reinvested earnings accounted for more than half of the growth in the stock of U.S. outward direct investment, 60 per cent in manufacturing and trade, and somewhat lower proportions in petroleum and in other industries including finance (Table 9).

Some more recent data, for countries that keep such records, are summarized in Table 10, for both home countries and host countries, 1989 through 1995. The large contribution of retained earnings to growth in direct investment, a characteristic of U.S. outward direct investment for so long, is not a universal characteristic of direct investment, as can be seen in the 
large negative retained earnings on inward direct investment in the United States. The importance of retained earnings appears to be related to the age of the investments, the U.S., the U.K., Sweden, and Switzerland being direct investors of long standing. Much of U.S. inward investment, on the other hand, is a product of the late 1980s, and, therefore very new during the period covered. Similarly, Germany is a relatively late entrant as a major direct investor, partly because much of its investment was confiscated after losses in two World Wars.

Other factors may also play a role. During the period of exchange controls, many enterprises were not permitted to repatriate their profits, particularly from developing countries. There are also differences and changes in systems of taxation of overseas earnings that affect where profits are made, where they are accumulated, and if and when they are repatriated.

\section{Summary}

Direct investment, as a flow of capital, is only partly related to the activities of multinational firms. Most of what these firms do and most of their impact, is unconnected with current capital flows and parts of the capital flows are unconnected with multinational firms. Over time, the definition of direct investment has shifted from an emphasis on control across national boundaries to a vaguer notion of "lasting interest" and a "significant" influence on management, and in the balance of payments data the enterprise is divided up statistically among owners of shares of 10 per cent or more.

The history of cross-border ownership of enterprises is a long one, and its importance as a part of international capital flows before World War I a matter of some controversy. However, it is clear that direct investment was more important in total U.S. investment abroad than in total foreign investment by other countries and far more important than in foreign investment in the 
United States. As a result of this specialization in direct investment, the United States was the dominant holder of direct investment assets in the decade or two after World War II.

It is hard to assess the relative importance of direct investment as a method of financing international investment flows because of the offsetting of one set of flows by another. In the gross flow data, direct investment has accounted for a little under a quarter of flows since 1989, and appears to have grown in importance since the 1970s.

The United States was by far the major source of direct investment outflows in the early 1970s but Europe soon caught up and Japan almost did before fading out in the 1990s. Hong Kong became a major investor in the 1990s, investing heavily in China. The United States shifted from being the world's largest net supplier of direct investment to being a large absorber of such investment from other countries, especially in 1985-89, and then reverted to its earlier net supplier role. Latin America and Southeast Asia have been continuous net recipients of direct investment.

Portfolio capital has been supplied to the world steadily by Japan. The United States, at times, particularly in 1985-89, has absorbed much of this capital, on net balance, and Southeast Asia and Latin America have also been major borrowers.

Total international capital flows, of which the United States supplied a large proportion through 1983, have since then become a source of capital for the United States, as they have been for China and Southeast Asia in almost every period. Europe also has been a net absorber of capital in most periods, and Japan the only consistent supplier.

In recent years, capital flows among the developed countries, particularly the United States and Europe, have been dominated by portfolio capital. Direct investment has played the 
largest role in net outflows from Japan and especially in the inflows to Southeast Asia, China, and Latin America.

The different forms of international investment flows not only vary in importance among regions but have different characteristics in other ways. Direct investment flows have been the least volatile among the different types in most countries, the chief exception being the United States, which has flipped back and forth from being the dominant net supplier to dominant net recipient and back to dominant net supplier. For other countries, and particularly for developing countries, direct investment has been the most dependable source of foreign investment.

One reason for the relative stability of direct investment flows may be the importance within them of retained earnings. These do fluctuate, of course, with profits, but they rarely shift sharply into the negative once firms are well established. Retained earnings appear to be most important in outward U.S. and U.K. investment. There are some large negative retained earnings in recent years for foreign direct investment in the United States, relatively new and perhaps purchased at the peak of real estate markets, but the general relationship seems to be that older holdings of direct investment grow a good deal from retained earnings. 


\section{References}

Bloomfield, Arthur I. (1968), Patterns of Fluctuations in International Investment Before 1914, Princeeton Studies in International Finance, No. 21, International Finance Section, Department of Economics, Princeton University, December.

Dunning, John (1970), Studies in International Investment, London, George Allen \& Unwin. Edelstein, Michael (1982), Overseas Investment in the Age of High Imperialism: The United Kingdom, 1850-1914, New York, Columbia University Press.

Hobson, C.K., The Export of Capital (1914), London, Constable and Co.

International Monetary Fund (1993), Balance of Payments Manual, 5th Edition, Washington, DC, International Monetary Fund. (1996). Balance of Payments Yearbook, 1996, Washington, D.C., International Monetary Fund. (1998). Diskette based on Balance of Payments Yearbook, 1997,

Washington, D.C., International Monetary Fund.

Iverson, Carl (1936), Aspects of the Theory of International Capital Movements, Levin \& Munksgaard, Copenhagen, and Humphrey Milford, Oxford University Press, London. Lewis, Cleona (1938), America's Stake in International Investments, Washington, DC, The Brookings Institution.

Mintz, Ilse (1951), Deterioration in the Quality of Foreign Bonds Issued in the United States, 1920 -1930, New York, National Bureau of Economic Research.

Organization for Economic Cooperation and Development (OECD), (1996), OECD Benchmark Definition of Foreign Direct Investment, Third Edition, Paris, OECD. 
, (1998), International Direct

Investment Statistics Yearbook, Paris, OECD.

Palgrave, Robert Harry Inglis, Editor (1910), Dictionary of Political Economy, London, Macmillan and Co.

Svedberg, Peter (1978), “The Portfolio-Direct Composition of Private Foreign Investment in 1914 Revisited," Economic Journal, No. 352, Vol. 88, December, pp.763-777. United Nations (1988), Transnational Corporations in World Development: Trends and Prospects, Centre on Transnational Corporations, New York, United Nations. (1995), World Investment Report, 1995, New York and Geneva, United Nations. (1996), World Investment Report, 1996, New York and Geneva, United Nations. (1997), World Investment Report, 1997, New York and Geneva, United Nations. (1998), World Investment Report, 1998, New York and Geneva, United Nations.

U.S. Bureau of the Census (1975), Historical Statistics of the United States, Colonial Times to 1970, Washington, D.C., U.S. Government Printing Office.

U.S. Department of Commerce (1937), Foreign Investments in the United States, Bureau of Foreign and Domestic Commerce, Washington, DC. (1953), Direct Private Foreign Investments of the United States,

Census of 1950, Office of Business Economics, Washington, DC. (1982), Selected Data on U.S. Direct Investment Abroad, 1950-

76, Bureau of Economic Analysis, Washington, D.C.

Wilkins, Mira (1977), “Modern European Economic History and the Multinationals,” Journal of European Economic History, Vol. 6, No.3, Winter, pp. 575-595. 
(1986), “Japanese Multinational Enterprise before 1914,” Business History

Review, 60, Summer. (1989), The History of Foreign Investment in the United States to 1914,

Cambridge, MA and London, Harvard University Press.

World Bank (1995), World Data 1995, World Bank Indicators on CD-ROM, Washington, DC, The World Bank.

World Bank (1997), World Development Indicators on CD-ROM, Washington, DC, The World Bank. 


\section{Table 1}

Growth in Three Forms of Capital Outflow

\section{0-94/1970-74}

\begin{tabular}{lr} 
Direct Investment & 61.7 \\
\hline Portfolio Investment & 49.6 \\
\hline Other Investment & 5.9 \\
\hline $1990-94 / 1980-84$ & \\
\hline Direct Investment & 5.24 \\
\hline Portfolio Investment & 5.97 \\
\hline Other Investment & 1.08
\end{tabular}

Source: Appendix Table 1, with 1970-74 estimated from 1980-84 overlap 
Table 2

Share of Direct Investment in Total Capital Outflow

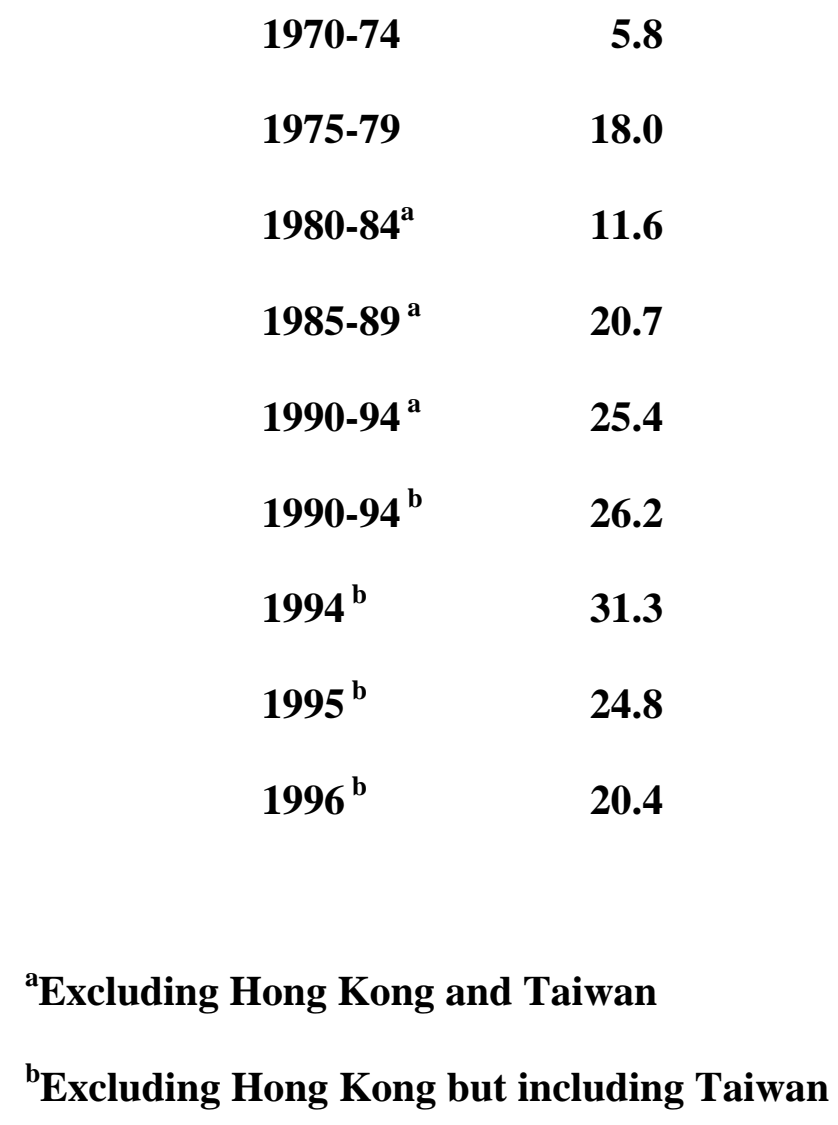

Source: Appendix Table 1, with 1970-74 and 1975-79 estimated from 1980-84 overlap 


\section{Table 3}

Reported Net Inflows of Portfolio Capital 1980-1996

(\$ Million)

\begin{tabular}{lr} 
United States & $\mathbf{\$ 6 5 0 , 1 8 0}$ \\
Japan & $\mathbf{- 5 0 6 , 3 2 0}$ \\
Europe & $\mathbf{2 7 6 , 2 0 0}$ \\
\hline Developing Asia & $\mathbf{8 6 , 1 2 8}$ \\
\hline Latin America & $\mathbf{2 7 3 , 7 7 1}$
\end{tabular}

Total

$1,286,279$

Source: Appendix Tables 2 and 3. 
Table 4

FREQUENCY OF SIGN CHANGES IN CAPITAL FLOWS, 1980-1995

(No. of Countries: 52)

No. of Sign Changes Average Frequency of Sign Changes

130

2.50

3.60

4.17
Average Duration of Run

6.40

4.45

3.83

Source: IMF (1998). 
Table 5

RATIOS OF STANDARD DEVIATIONS TO MEANS FOR VARIOUS

TYPES OF INTERNATIONAL

CAPITAL FLOWS, 1969-1993

Net FDI $\begin{gathered}\text { Other LT, Portfolio } \\ \text { incl. } \\ \text { Portfolio }\end{gathered}$

$\begin{array}{lcccc}\text { United States } & 1.302 & 1.469 & 1.188 & 1.297 \\ \text { Japan } & 1.307 & 1.371 & 1.473 & 1.636 \\ & & & & \\ \text { SE Asia } & & & & \\ \begin{array}{l}\text { Unweighted Average } \\ \text { Aggregate }\end{array} & 1.373 & 1.857 & 1.658 & 1.561 \\ & 1.455 & 2.265 & 1.835 & 1.179 \\ \text { Europe } & & & & \\ \begin{array}{l}\text { Unweighted Average } \\ \text { Aggregate }\end{array} & 1.311 & 1.524 & 1.625 & 1.708 \\ \quad \text { Latin America } & 1.008 & 1.911 & 2.102 & 1.823 \\ \begin{array}{l}\text { Unweighted Average } \\ \text { Aggregate }\end{array} & 1.072 & 1.792 & 2.228 & 1.478 \\ & 0.819 & 1.781 & 2.278 & 1.484\end{array}$

${ }^{a}$ Unweighted average of standard deviations for individual countries.

${ }^{\mathrm{b}}$ Standard deviation of aggregate net flows to or from region. 
Table 6

\section{SUMMARY OF EQUATIONS RELATING FDI BY A COUNTRY TO FDI IN A COUNTRY, 1969-1994}

\begin{tabular}{|c|c|c|c|c|}
\hline & \multicolumn{2}{|c|}{ FDI By=f(FDI In) } & \multicolumn{2}{|c|}{ FDI By/GDP=f(FDI In/GDP) } \\
\hline & $\begin{array}{c}\text { Coefficient } \\
\text { of FDI in }\end{array}$ & Adj. R sq. & $\begin{array}{l}\text { Coefficient of } \\
\text { FDI/GDP in }\end{array}$ & Adj. R sq. \\
\hline \multirow[t]{2}{*}{ USA } & 0.45 & $0.16^{*}$ & -0.05 & -0.04 \\
\hline & $(2.40)$ & & $(0.18)$ & \\
\hline \multirow[t]{2}{*}{ UK } & 1.01 & $0.66 * *$ & 0.73 & $0.32 * *$ \\
\hline & $(7.02)$ & & $(3.53)$ & \\
\hline \multirow[t]{2}{*}{ Japan } & 4.13 & 0.01 & -3.68 & 0.03 \\
\hline & $(1.09)$ & & $(1.33)$ & \\
\hline \multirow[t]{2}{*}{ Germany } & 2.26 & $0.60 * *$ & 0.51 & 0.05 \\
\hline & $(6.26)$ & & $(1.48)$ & \\
\hline \multirow[t]{2}{*}{ France } & 1.49 & $0.85 * *$ & 1.62 & $0.71 * *$ \\
\hline & $(12.02)$ & & $(7.70)$ & \\
\hline \multirow[t]{2}{*}{ Netherlands } & 1.47 & $0.83 * *$ & 1.04 & $0.47 * *$ \\
\hline & $(11.27)$ & & $(4.68)$ & \\
\hline \multirow[t]{2}{*}{ Sweden } & 1.11 & $0.28 * *$ & 1.20 & $0.18^{*}$ \\
\hline & $(3.26)$ & & $(2.51)$ & \\
\hline \multirow[t]{2}{*}{ Canada } & 0.49 & $0.36 * *$ & 0.06 & -0.04 \\
\hline & $(3.81)$ & & $(0.38)$ & \\
\hline \multirow[t]{2}{*}{ Brazil } & -0.01 & -0.04 & -0.06 & 0.12 \\
\hline & $(0.14)$ & & $(2.06)$ & \\
\hline \multirow[t]{2}{*}{ Singapore } & 0.14 & $0.57 * *$ & 0.09 & 0.07 \\
\hline & $(5.40)$ & & (1.59) & \\
\hline \multirow[t]{2}{*}{ ALL } & 0.76 & $0.38 * *$ & 0.09 & $0.03 * *$ \\
\hline & $(12.55)$ & & $(3.03)$ & \\
\hline
\end{tabular}

Numbers in parentheses are t-statistics

* Prob $\mathrm{F}<0.05$

$* *$ Prob $\mathrm{F}<0.01$ 


\section{Table 7}

Simple Regressions Relating FDI Flows to Flows of Other Types of Capital 13 Countries

\begin{tabular}{|l|c|c|}
\hline & Coefficient of FDI & $\overline{\mathrm{R}}^{2}$ \\
\hline Outward FDI x Short-term Capital & $.230^{* *}$ & .148 \\
Outward FDI x LT Capital exc. FDI & -.016 & -.003 \\
Outward FDI x Portfolio Capital & $.080^{*}$ & .014 \\
Net FDI x Short-term Capital & $.059^{*}$ & .012 \\
Net FDI x LT Capital exc. FDI & $-.097^{* *}$ & .039 \\
Net FDI x Portfolio Capital & $-.121^{* *}$ & .059 \\
\hline
\end{tabular}

*Significant at 5 per cent level

**Significant at 1 per cent level 
Table 8

Distribution, by Type, of U.S. Outflows of Direct Investment

$\begin{array}{ccc}\begin{array}{c}\text { Equity Capital } \\ \text { Outflows }\end{array} & \text { Retained } & \text { Intercompany } \\ \text { Earnings } & \text { Debt Outflows }\end{array}$

\begin{tabular}{cccc}
$1982-86$ & 26.7 & 84.9 & -11.6 \\
$1987-91$ & 23.6 & 64.6 & 11.8 \\
$1992-95$ & 34.2 & 50.7 & 15.0 \\
1992 & 37.6 & 41.8 & \\
1993 & 33.0 & 40.4 & 20.6 \\
1994 & 24.8 & 62.4 & 26.6 \\
1995 & 39.0 & 56.3 & 12.8 \\
\hline
\end{tabular}

Source: BEA diskette on "U.S. Direct Investment Abroad: Balance of Payments and Direct Investment Position.” Intracompany transactions with the Netherlands Antilles have been removed. 
Table 9

Cumulated Reinvested Earnings and Changes in U.S. Outward Direct Investment Stock Total and Selected Industry Groups, 1950-1975

(\$ Billion)

\begin{tabular}{|c|c|c|c|c|}
\hline & $\begin{array}{c}\text { Change in } \\
\text { Direct } \\
\text { Investment } \\
\text { Stock }\end{array}$ & $\begin{array}{c}\text { Investment } \\
\text { Stock } \\
1975 / 1950\end{array}$ & $\begin{array}{c}\text { Cumulated } \\
\text { Reinvested } \\
\text { Earnings }\end{array}$ & $\begin{array}{c}\text { Share of } \\
\text { Reinvested } \\
\text { Earnings }\end{array}$ \\
\hline All Industries & 112 & 10.5 & 60 & 54 \\
\hline Petroleum & 23 & 7.7 & 10 & 43 \\
\hline $\begin{array}{c}\text { Manufacturing } \\
\text { Trade }\end{array}$ & 52 & 14.6 & 31 & 60 \\
\hline $\begin{array}{c}\text { Other, incl. } \\
\text { Finance }\end{array}$ & 19 & 16.4 & 7.5 & 37 \\
\hline
\end{tabular}

Source: U.S. Department of Commerce (1982). 
Table 10

Outflows and Inflows of Direct Investment:

Total and Reinvested Earnings

Selected Countries, 1989-1995

\begin{tabular}{|l|r|r|r|r|r|c|}
\hline & $\begin{array}{c}\text { Total Direct } \\
\text { Investment } \\
\text { Assets } \\
\text { (Outward FDI }\end{array}$ & $\begin{array}{c}\text { Reinvested } \\
\text { Earnings }\end{array}$ & $\begin{array}{c}\text { Share of } \\
\text { Reinvested } \\
\text { Earnings } \\
(\%)\end{array}$ & $\begin{array}{c}\text { Total Direct } \\
\text { Investment } \\
\text { Liabilities } \\
\text { (Inward FDI) }\end{array}$ & $\begin{array}{c}\text { Reinvested } \\
\text { Earnings }\end{array}$ & $\begin{array}{c}\text { Share of } \\
\text { Reinvested } \\
\text { Earnings } \\
(\%)\end{array}$ \\
\hline U.S. & $\mathbf{3 6 8 , 9 8 8}$ & $\mathbf{1 8 4 , 5 0 8}$ & $\mathbf{5 0 . 0}$ & $\mathbf{3 0 8 , 2 4 2}$ & $-\mathbf{- 4 7 , 5 8 2}$ & \multicolumn{1}{|c|}{} \\
\hline Germany & $\mathbf{1 4 9 , 7 0 0}$ & $\mathbf{1 0 , 8 4 9}$ & $\mathbf{7 . 2}$ & $\mathbf{2 8 , 0 0 5}$ & $-\mathbf{6 , 6 8 7}$ & $\mathbf{- 2 3 . 9}$ \\
\hline Netherlands & $\mathbf{8 6 , 5 4 9}$ & $\mathbf{9 , 1 5 9}$ & $\mathbf{1 0 . 6}$ & $\mathbf{4 8 , 0 2 5}$ & $\mathbf{8 , 2 2 5}$ & $\mathbf{1 7 . 1}$ \\
\hline Sweden & $\mathbf{5 1 , 4 0 6}$ & $\mathbf{1 2 , 7 4 2}$ & $\mathbf{2 4 . 8}$ & $\mathbf{3 4 , 3 5 9}$ & $\mathbf{4 , 3 2 7}$ & 12.6 \\
\hline Switzerland & $\mathbf{5 7 , 8 8 5}$ & $\mathbf{1 5 , 7 2 9}$ & $\mathbf{2 7 . 2}$ & $\mathbf{1 9 , 8 1 8}$ & $\mathbf{7 , 8 0 5}$ & $\mathbf{3 9 . 4}$ \\
\hline U.K. & $\mathbf{1 8 4 , 2 3 0}$ & $\mathbf{1 0 8 , 9 0 8}$ & $\mathbf{5 9 . 1}$ & $\mathbf{1 5 3 , 3 7 5}$ & $\mathbf{3 2 , 0 4 7}$ & $\mathbf{2 0 . 9}$ \\
\hline
\end{tabular}

${ }^{\mathrm{a} 1989-1994}$

Source: International Monetary Fund (1996). 


\section{APPENDIX TABLE 1 \\ WORLD INVESTMENT FLOWS \\ \$ MILLIONS \\ 5-YEAR AVERAGES, 1970-1984}

\begin{tabular}{|c|c|c|c|c|}
\hline & $\begin{array}{c}\text { DIRECT } \\
\text { INVESTMENT }\end{array}$ & $\begin{array}{l}\text { PORTFOLIO } \\
\text { INVESTMENT }\end{array}$ & $\begin{array}{c}\text { OTHER } \\
\text { INVESTMENT }\end{array}$ & TOTAL \\
\hline $1970-1974$ & 3,564 & 5,081 & 26,608 & \\
\hline $1975-1979$ & 36,669 & 14,493 & 76,336 & \\
\hline $1980-1984$ & 44,751 & 42,247 & 145,149 & \\
\hline \multicolumn{5}{|c|}{ CURRENT IMF DATA, 1980-1996 } \\
\hline 1980-1984 & $44,514^{a}$ & $59,316^{a}$ & $279,690^{a}$ & 383,520 \\
\hline $1985-1989$ & $140,069^{a}$ & $188,670^{a}$ & $346,895^{a}$ & 675,634 \\
\hline $1990-1994$ & $219,969^{a}$ & $352,784^{a}$ & $294,752^{a}$ & 867,505 \\
\hline 1990-1994 & 233,409 & $353,927^{b}$ & $303,104^{b}$ & 890,440 \\
\hline 1994 & 276,443 & $330,662^{b}$ & $276,721^{b}$ & 883,826 \\
\hline 1995 & 349,501 & $372,438^{b}$ & $684,525^{b}$ & $1,406,464$ \\
\hline 1996 & 348,992 & $587,069^{b}$ & $778,432^{b}$ & $1,714,493$ \\
\hline
\end{tabular}

${ }^{a}$ Excluding Hong Kong and Taiwan

${ }^{\mathbf{b}}$ Including Taiwan but not Hong Kong

Sources: IMF (1998), World Bank (1995) and (1997), United Nations (1996), (1997), and (1998). 
APPENDIX TABLE 2

SOURCES OF DIRECT INVESTMENT OUTFLOWS

\begin{tabular}{lrrrrr}
\multicolumn{7}{c}{$\begin{array}{l}\text { \$ MILLIONS } \\
\text { 5-YEAR AVERAGES, 1970-1984 }\end{array}$} \\
\hline US & JAPAN & EUROPE & $\begin{array}{c}\text { DEVPG } \\
\text { ASIA }\end{array}$ & $\begin{array}{c}\text { LATIN } \\
\text { AMERICA }\end{array}$ \\
$1970-1974$ & 8,670 & 1,042 & 6,968 & 23 & 31 \\
$1975-1979$ & 15,876 & 2,133 & 16,000 & 109 & 194 \\
$1980-1984$ & 10,117 & 4,280 & 24,889 & 240 & 358 \\
$1980-1984$ & 9,592 & 4,280 & 24,958 & $163^{\mathrm{a}}$ & 262 \\
$1985-1989$ & 22,890 & 24,590 & 75,591 & $6,168^{\mathrm{b}}$ & 411 \\
$1990-1994$ & 50,240 & 26,286 & 121,846 & $22,696^{\mathrm{c}}$ & 1,625 \\
1994 & 69,264 & 18,089 & 131,789 & $36,302^{c}$ & 2,936 \\
1995 & 86,738 & 22,508 & 177,416 & $42,180^{c}$ & 2,797 \\
1996 & 87,812 & 23,442 & 172,053 & $48,024^{c}$ & 3,770
\end{tabular}

${ }^{\text {a }}$ Excluding Hong Kong \& Taiwan.

${ }^{b}$ Excluding Hong Kong but including annual average outward direct investment by Taiwan over the period 1984-89.

${ }^{\mathrm{c}}$ Including both Hong Kong \& Taiwan.

Sources: IMF (1998), World Bank (1995) and (1997), United Nations (1996), (1997), and (1998). 
APPENDIX TABLE 3

DESTINATIONS OF DIRECT INVESTMENT INFLOWS

\begin{tabular}{|c|c|c|c|c|c|}
\hline \multicolumn{6}{|c|}{$\begin{array}{c}\text { \$ MILLIONS } \\
\text { 5-YEAR AVERAGES, 1970-1984 }\end{array}$} \\
\hline & US & JAPAN & EUROPE & $\begin{array}{l}\text { DEVPG } \\
\text { ASIA }\end{array}$ & $\begin{array}{l}\text { LATIN } \\
\text { AMERICA }\end{array}$ \\
\hline 1970-1974 & 2,070 & 126 & 7,181 & 708 & 1,308 \\
\hline $1975-1979$ & 6,092 & 123 & 11,474 & 1,423 & 3,270 \\
\hline $1980-1984$ & 17,965 & 262 & 15,202 & 3,641 & 5,214 \\
\hline \multicolumn{6}{|c|}{ CURRENT IMF DATA, 1980-1996 } \\
\hline 1980-1984 & 17,965 & 262 & 15,536 & $4,716^{a}$ & 6,308 \\
\hline 1985-1989 & 47,773 & 101 & 46,226 & $11,512^{b}$ & 6,505 \\
\hline 1990-1994 & 36,507 & 1,371 & 91,489 & $36,182^{b}$ & 15,287 \\
\hline 1994 & 45,678 & 912 & 84,642 & $59,753^{b}$ & 27,495 \\
\hline 1995 & 67,527 & 39 & 138,030 & $68,385^{b}$ & 28,838 \\
\hline 1996 & 76,955 & 200 & 120,109 & $77,995^{b}$ & 40,056 \\
\hline
\end{tabular}

${ }^{a}$ Including annual average figures for outward direct investment by Hong Kong \&Taiwan over the period 1980-85.

${ }^{\mathbf{b}}$ Including both Hong Kong \& Taiwan.

Sources: IMF (1998), World Bank (1995) and (1997), United Nations (1996), (1997), and (1998). 


\begin{abstract}
APPENDIX TABLE 4
NET INFLOWS* OF DIRECT INVESTMENT, FIVE REGIONS
\end{abstract}

$\$$ MILLIONS

5-YEAR AVERAGES, 1970-1984

\begin{tabular}{lrrrrr}
\hline & US & JAPAN & EUROPE & $\begin{array}{c}\text { DEVPG } \\
\text { ASIA }\end{array}$ & $\begin{array}{r}\text { LATIN } \\
\text { AMERICA }\end{array}$ \\
$1970-1974$ & $-6,600$ & -916 & 213 & 685 & 1,277 \\
$1975-1979$ & $-9,784$ & $-2,010$ & $-4,526$ & 1,314 & 3,076 \\
$1980-1984$ & 7,847 & $-4,018$ & $-9,688$ & 3,401 & 4,855 \\
& CURRENT IMF DATA, 1980-1996 & \\
$1980-1984$ & 8,373 & $-4,018$ & $-9,422$ & 4,553 & 6,045 \\
$1985-1989$ & 24,883 & $-24,489$ & $-29,365$ & 5,344 & 6,094 \\
$1990-1994$ & $-13,733$ & $-24,915$ & $-30,357$ & 13,486 & 13,662 \\
1994 & $-23,586$ & $-17,177$ & $-47,147$ & 23,451 & 24,559 \\
1995 & $-19,211$ & $-22,468$ & $-39,386$ & 26,204 & 26,041 \\
1996 & $-10,857$ & $-23,242$ & $-51,945$ & 29,970 & 36,286 \\
\hline
\end{tabular}

${ }^{*}$ net flows are inflows minus outflows

${ }^{a}$ Excluding Hong Kong and Taiwan

Including Taiwan and outward investment from Hong Kong, but including inward investment

Including Hong Kong and Taiwan

Sources: Appendix Tables 2 and 3. 
APPENDIX TABLE 5

NET FLOWS* OF PORTFOLIO CAPITAL, BY REGION

\begin{tabular}{|c|c|c|c|c|c|}
\hline \multirow[b]{3}{*}{$1970-1974$} & \multicolumn{4}{|c|}{$\begin{array}{c}\text { \$ MILLIONS } \\
\text { 5-YEAR AVERAGES, 1970-1984 }\end{array}$} & \multirow[b]{2}{*}{$\begin{array}{l}\text { LATIN } \\
\text { AMERICA }\end{array}$} \\
\hline & US & JAPAN & EUROPE & $\begin{array}{l}\text { DEVPG } \\
\text { ASIA } \\
\text { INC TAIWAN }\end{array}$ & \\
\hline & 5,494 & -292 & -691 & 54 & -18 \\
\hline $1975-1979$ & 8,140 & 392 & 3,014 & 254 & 790 \\
\hline 1980-1984 & 12,449 & $-1,784$ & $-4,521$ & 576 & 1,568 \\
\hline \multicolumn{6}{|c|}{ CURRENT IMF DATA, 1980-1996 } \\
\hline 1980-1984 & 12,449 & $-1,908$ & $-12,981$ & 810 & 1,661 \\
\hline 1985-1989 & 70,229 & $-69,458$ & 23,802 & 1,749 & -118 \\
\hline 1990-1994 & 14,380 & $-14,354$ & 39,192 & 8,231 & 40,225 \\
\hline 1994 & 79,091 & $-27,219$ & $-66,265$ & 13,408 & 65,989 \\
\hline 1995 & 137,401 & $-36,575$ & 51,246 & 14,593 & 4,827 \\
\hline 1996 & 274,879 & $-41,145$ & $-25,111$ & 17,585 & 60,104 \\
\hline
\end{tabular}

${ }^{*}$ Inflows minus outflows

Sources: IMF (1998) and World Bank (1995) and (1997) 
APPENDIX TABLE 6

\section{NET FLOWS* OF OTHER INVESTMENT, BY REGION}

$\$$ MILLIONS

5-YEAR AVERAGES, 1970-1984

\begin{tabular}{lrrrrr}
\hline & US & JAPAN & EUROPE & $\begin{array}{c}\text { DEVPG } \\
\text { ASIA } \\
\text { INC TAIWAN }\end{array}$ & \multicolumn{1}{c}{$\begin{array}{c}\text { LATIN } \\
\text { AMERICA }\end{array}$} \\
& \multicolumn{5}{c}{ CURRENT IMF DATA, 1980-1996 } \\
$1980-84$ & $-14,399$ & $-5,428$ & 42,073 & 20,639 & 22,477 \\
$1985-89$ & 29,093 & 36,522 & 1,468 & 9,769 & 2,895 \\
$1990-94$ & 85,088 & $-37,926$ & 34,187 & 11,156 & $-9,412$ \\
1994 & 75,967 & $-40,714$ & 89,957 & 9,973 & $-43,513$ \\
1995 & 35,579 & $-4,936$ & 7,841 & 26,475 & 28,023 \\
1996 & $-75,558$ & 36,288 & 53,420 & 46,640 & $-22,922$ \\
\hline
\end{tabular}

${ }^{*}$ net flows are outflows less inflows

The figures for $1980-84,1985-89$ and 1990-94 are annual averages

Sources: IMF (1998) and World Bank (1995) and (1997) 


\section{APPENDIX TABLE 7}

\section{TOTAL AVERAGE ANNUAL NET INTERNATIONAL CAPITAL FLOWS, *}

BY REGION

\begin{tabular}{lrrrrr}
\multicolumn{6}{c}{ \$ MILLIONS } \\
\hline US & JAPAN & EUROPE & $\begin{array}{c}\text { DEVPG } \\
\text { ASIA } \\
\text { INC HONG KONG }\end{array}$ & LATIN AMERICA \\
$1980-84$ & 6,423 & $-11,354$ & 19,670 & 26,002 & 30,183 \\
$1985-89$ & 124,205 & $-57,425$ & $-4,094$ & 16,863 & 8,871 \\
$1990-94$ & 85,735 & $-77,195$ & 43,022 & 32,873 & 44,474 \\
1994 & 131,472 & $-85,110$ & $-23,455$ & 46,832 & 47,036 \\
1995 & 153,769 & $-63,980$ & 19,701 & 67,272 & 58,891 \\
1996 & 188,464 & $-28,098$ & $-23,636$ & 94,195 & 73,469 \\
\hline
\end{tabular}

${ }^{*}$ net flows are outflows less inflows

Source: World Bank World Tables CD-ROM and IMF Balance of Payments Yearbook 